\title{
Medicine and Health Care in Early Christianity
}

\author{
by Gary Ferngren
}

Baltimore: Johns Hopkins University Press, 2009. xi + 264 pp.

Over the centuries since Jesus Christ walked the earth, many theologians have held that the earliest Christian communities eschewed the traditional medicine of their time in favor of seeking cures from religiously-based prayers and practices, since such therapies played such a large role in the ministry of Jesus and his apostles. In this book, historian Gary Ferngren argues that these Christian communities held the same attitudes toward traditional medicine as did their non-Christian contemporaries. He does, however, note that Christian philanthropy was motivated by Christ-like agapeic service, a view not shared by pagan cultures.

In the first part of the book, the author discusses traditional Greco-Roman medicine and the Christian acceptance of it. Greco-Roman medicine was not monolithic in how it regarded the etiologies and therapies of illnesses, and so a variety of views were acceptable. Although a few practitioners undoubtedly regarded illness to be caused by the anger of the gods or demon-possession, most practitioners of the day looked for natural causes of illness, whether internal or external to the person suffering. Hence there existed-side-byside-"medical, religious, folk, and magical healing traditions" (37). Because there was no formal medical profession as we understand it today, and no licensing procedures or standards of care existed, individuals who were ill sought care from those whom they knew well first; only then, when an illness was not healed by the recommendations of family, friends, or local healers did individuals seek help outside their social circles. That might mean appeal to physicians or to holy men.

Ferngren does not find any substantial evidence that the majority of Jews in Jesus' time and Christians in the first few centuries believed in demon-possession and the need for exorcisms as a way to heal most illnesses. Instead, he believes that the preponderance of evidence is that "[d]isease and impairment were one of the aspects of material (as distinct from moral) evil that resulted from the Fall of the human race into sin.... When Christians thought disease to be generic in the human race, popular opinion often viewed it as God's retribution for personal or hereditary sin; it was the dominant theodicy of the ancient world" (59-60). Ferngren notes that Christians "valued medicine as God's gift for the natural healing of disease," citing the words of Sirach 38: 1, 6-7: "Honor the physician with the honor due to him, before you need him.... [For] he [Yahweh] gave skill to men that he might be glorified in his marvelous works" (61). For this reason, Ferngren does not hold the view that Christianity's appeal was primarily as a religion of healing to explain its exponential growth in its earliest centuries.

In the second part of the book, it is in the area of philanthropy that the author finds a clear divergence of Christian practice from that of the Greco-Roman culture.

Philanthropy among the Greeks did not take the form of private charity or of a personal concern for those in need, such as orphans, widows, or the sick. There was no religious or ethical impulse for almsgiving; ... In contrast with the emphasis in Judaism on God as particularly concerned for the welfare of the poor, the Greek and Roman gods showed little pity on them; indeed, they showed greater regard for the powerful who could offer them sacrifices. (87)

In the Roman world, human worth was not intrinsic but something that had to be earned by practicing the virtues expected of educated people (95). Jews and Christians believed that human worth was predicated on the fact that each person was created in the image and likeness of God, which-for Christians-was directly stated in Matthew 25: "Whatever you do to the least of these, you do to me." Furthermore, the classical concept of philanthropy benefitted the community at large, not individ- 
uals, and certainly not individuals whom society would consider the "least." Although all physicians were likely to have endeavored to do no harm in the practice of their craft, Christian physicians were certainly more likely to help the poor than were their pagan counterparts and to oppose abortion and exposure of unwanted infants and older individuals (107). This is because Christian physicians (and all Christians, for that matter) were to be guided by compassion and agapeic love, the kind of love that serves without asking anything in return. Compassion requires "an intuitive identification with the pain and suffering of another person" (108). Such agapeic love is rooted in the self-giving, incarnational, redemptive love of God in Jesus (114).

With this understanding, the Good Samaritan parable becomes the "model of Christian agape" (109) and service. And it became the guiding narrative when diseases and plagues attacked Christians and non-Christians alike. Christians were to care for all those in need, not just their own. So well did the early Christians care for all those in need that certain emperors complained that the Christians were exposing the government's deficiencies in the care of the populace! Care of the ill was a natural in monasteries which welcomed strangers as well as their own, and whose members took Matthew 25 very seriously. Over time, the monks developed their skills and were quite good at providing care.

While physicians applied therapies that were informed by Galenic medicine, their therapies may not have differed appreciably from those of monks who were well-informed about medical theory and skilled in offering care. Hence, one might be hard pressed in certain instances to distinguish the treatment provided by an experienced caregiver from that prescribed by a physician. (127)

These early monastic hospitals were the predecessors of our modern Christian- (especially Catholic-) affiliated hospitals, and the monks were the forefathers of modern practitioners who provide care to the ill and needy, regardless of ability to pay, race, ethnic group, or religious affiliation.

In this book, Ferngren includes fiftythree pages of notes to buttress his findings and ideas; there is also a twenty-eight-page bibliography. He has done an enormous amount of research, which he gladly shares with readers. He is not reluctant to point out the issues over which other historians do not agree with him, readily citing their opinions, even while producing evidence for his own ideas.

Ferngren writes in an engaging manner that will be especially attractive to physicians who do not have a background in theology or Church history. This book would be of great interest to any Christian physician or health-care professional who is interested in learning more about medicine at the time of Christ and its impact on Christianity and, perhaps more importantly, Christianity's impact on the care of the ill. It is the latter that can inform the care of the ill and needy in our own time, as the larger health-care profession struggles with its inability to serve all those who require care, especially in the midst of the economic climate in which we find ourselves.

Patricia Fosarelli, M.D., D.Min. Associate Dean

The Ecumenical Institute of Theology Baltimore, Maryland 